\title{
京都市内孤立林における シダ植物の種多様性に関する景観生態学的研究
}

\author{
村上健太郎 ${ }^{1}$ ・森本幸裕 ${ }^{2}$ \\ 1 きしわだ自然資料館 596-0072 大阪府岸和田市堺町 6-5 \\ 2 京都大学大学院農学研究科 606-8502 京都市左京区北白川追分町
}

\section{Landscape ecological study on the Pteridophyta species richness in fragmented forest patches in Kyoto city area}

Kentaro MURAKAMI ${ }^{1}$ and Yukihiro MORIMOTO ${ }^{2}$

${ }^{1}$ Natural History Musium, Kishiwada City, 6-5 Sakai-machi, Kishiwada-shi, Osaka, 596-0072 Japan

${ }^{2}$ Laboratory of Landscape architecture, Graduate School of Agriculture, Kyoto University,

Kitashirakawa Oiwake-cho, Sakyo-ku, Kyoto, 606-8502 Japan

はじめに

孤立林における生物種は, 生物分類ごとに分布 パターンが異なっている（Forman, 1995 ; 夏原, 2000). 都市緑地環境の保全目標を特定の種, 生物 群の保護ではなく, 生態系全体の保護, 健全性の回 復に置くのであれば，それぞれの分類群ごとに分 布パターンを比較することが必要である。シダ植 物は，孤立林の小面化にともなって激減するとい う報告（服部・石田，2000；石田ほか，1998）があ り，都市孤立林においては注目すべき生物群の一 つであると言える。

これらのことから，本研究では都市内孤立林に おけるシダ植物の種数に着目し, 種数と, 種数に影 響すると考えられている面積や比高（標高差），八 ビタット単位数などとの関係について検討した.

\section{調查地域と調查方法}

調査地域は，京都市の都市域に設定した。この 範囲は，既報（村上・森本，2000）と同様である. 調査地点とした孤立林は 38 箇所であり, 調査地域 内に見られる孤立林をできるかきりり網羅的に選定 した. 調査地点の孤立林の中には, 植栽, 竹林など も林内に含まれているものもあるが，植栽のみか らなる公園や庭園, 竹林のみの孤立林については, 調査対象から除外した。調查地点の孤立林は, 過去 の地形図の判読から，少なくとも孤立林として成 立してから 35 年以上は経過している.

調査地域は，住宅地や商業施設が密に見られる 都市部にあり, 調查地点の多くの箇所で, 造園植栽 や植林，歩道などが見られ，人為的な影響が大き い.しかし，これらは都市内孤立林の特性と考え， 本研究ではこうした箇所も調査対象に含めた。

野外調査としては，調査地点の孤立林内を可能
な限りくまなく歩き，孤立林内に出現するシダ植 物の種数を記録した. 調查対象とした植物は, 一般 にシダ植物と呼ばれているヒカゲノカズラ綱，卜 クサ綱, マッバラン綱, シダ綱の4綱の植物である. 分類は岩槻 (1992) に従い, 種および亜種までの区 分を行った.よって, 本研究で種数という場合は, 亜種も含んだ数である。

また，各孤立林ごとにシダ植物にとってのハビ タット単位数を現地調査によって調べた。ハビ タットの区分としては，例えば地形学の観点から 区分された微地形単位が挙げられている（田村, 1990).ここで言う微地形単位とは, 頂部平坦面, 頂部斜面の尾根系列の単位から谷壁斜面, 谷底へ と至る谷系列の単位までを区分したものである。 また，シダ植物にとってのハビタットとして挙げ られている石垣および人工水路, 倒木, 湿った岩上 についてもマイクロハビタット単位としてその数 を調べた。

比高, 樹冠面積等については, 空中写真（1： 15000 ；平成 4 年京都市撮影）および京都市都市計 画図 $(1: 2500 ;$ 平成 7 年京都市撮影, 測量) を用 いて室内で計測した。

シダ植物の分布は，林内およびその周辺環境の 変化等によって，ある程度の年変動も考えられる。 よって,これらの調査は現在も継続中である.今回 の報告については，2000年 6 月〜 2001 年 4 月まで に,それぞれの調査地点において少なくとも2度以 上の調査を行い，種を記録した結果である。

\section{結果と考察}

\section{1. 種数 - 面積関係}

出現したシダ植物の全種数は 19 科 66 種であっ 
た. 各調査地点に出現したシダ植物の（S）と樹冠 面積（A ha）との関係は, Gleason（1922）の片対 数モデルを用いると，

$\mathrm{S}=4.10 \log \mathrm{A}+11.51\left(\mathrm{R}^{2}=0.63\right)$

の回帰式で示され,有意な正の相関が見られた。 これにより, シダ植物の種数の増減は, 面積の大 小と対応していると言える。

\section{2. 種数と比高及びハビタット単位数との関係}

更に, 孤立林 38 箇所の比高と種数との相関を調 べたところ，有意な正の相関が得られた．孤立林 の比高と植物の種数が正の相関を持っていること は既に指摘されている（服部・石田, 2000 ; 石田 ほか，1998）が, 本研究もこれらと同様であった。

ところで，種数と面積の間に正の相関が見られ る理由は, 確率論的な種数の増減だけではなく,小 面積化とともに植物にとってのハビタットも減少 するためだと考えられている（服部・石田，2000； 石田ほか，1998）。これについて検討するために， 調査地点ごとの微地形単位数およびマイクロハビ タット単位数と,種数との相関を調べたところ,い ずれについても有意な正の相関が得られた。

本研究が調査対象とした京都市内は, 低平な孤 立林が比較的多く残存している。 また，その中に は，京都御苑や下鴨神社などの大規模な孤立林も 含まれている。そのため, 大規模な孤立林が, 必 ずしも多様な微地形単位を有しているわけではな い. しかし, 微地形単位以外のマイクロハビタッ トも，シダ植物の種数に影響していると考えられ る．特に都市内の孤立林では，林床が必ずしもシ ダ植物にとっての好適なハビタットになるわけで はなく，人工的な環境であっても，石垣の隙間や 人工水路などの適湿地が重要であると考えられる. 実際，調査地域内で石垣および人工水路において 確認できたシダ植物はベニシダ, トラノオシダ, イ ノモトソウ, ヤブソテツ,ノキシノブ, シケシダ, オニヤブソテッ, ヤワラシダ, オクマワラビ, ヤ マヤブソテッ, ハカタシダ, オオイタチシダ, ト キワトラノオ, イヌケホシダ, ミッデウラボシの 16種に及び, これは全出現種の $24.2 \%$ に達した. 都 市内孤立林においては，このようなマイクロハビ タットの多様性も緑地面積の大小と対応している ため, シダ植物の種数の増減と緑地面積の大小が 対応すると考えられる。

\section{おわりに}

都市内において, 復元ないしは回復緑化として
造成されるビオトープの多くは，孤立林としての 性格を有していることが多い.また, 都市内は土地 利用上の制限が多いため，それらは小面積の場合 が多い.小面積の孤立緑地において,多様な生物相 を創出するのは，都市内のビオトープを環境教育 の場，自然とのふれあいの場として考えた場合に は重要な課題となるが, 種数一面積関係に基づけ ば, 小面積林においては, 長期的に高い種多様性を 維持するのは困難と考えられる。しかし, シダ植物 の場合, 都市内の小面積孤立林であっても, 微地形 単位や石垣，水路等のマイクロハビタットを多様 に設定することで，ある程度シダ植物の種数を確 保できるかもしれない.

しかし一方で, シダ植物の種多様性には土壤や 孤立度, パッチの形状, 樹林夕イプなどさまざまな 要素が影響している.これらについては,より詳細 な調査, 解析を必要とするため, 次報以降にさらに 詳しく論じたい.

\section{引用文献}

Forman,R.T.T. 1995. Land Mosaics - The ecology of landscapes and regions-. 632pp. Cambridge University Press, Cambridge.

Gleason,H.A. 1922. On the relation between species and area, Ecology 3: 158-162.

服部保・石田弘明. 2000. 宮崎県中部における照葉 樹林の樹林面積と種多様性，種組成の関係，日 本生態学会誌 50(3): 221-234.

石田弘明・服部保・武田義明・小舘誓治. 1998．兵 庫県南東部における照葉樹林の樹林面積と種多 様性，種組成の関係，日本生態学会誌 48(1): 116.

岩槻邦男編. 1992. 日本の野生植物 シダ. $311 \mathrm{pp}$. 平凡社, 東京.

村上健太郎・森本幸裕. 2000. 京都市内孤立林にお ける木本植物の種多様性とその保全に関する景 観生態学的研究, 日本緑化工学会誌 25(4): 345350.

夏原由博. 2000. 生きものからみた都市デザイン, 国際景観生態学会日本支部会報 5(3): 81-82.

田村俊和. 1990. ミクロな自然環境要素のとらえ 方，丘陵地の自然環境 - その特性と保全-（松 井健 - 武内和彦 - 田村俊和編), 47-54. 古今書 院，東京. 